\title{
OPME (Objectives-Process-Methods-Evaluation) Method for Lesson Planning
}

\author{
Yong Wei \\ College of Engineering and Technology \\ Tianjin Agricultural University \\ Tianjin, China \\ 595183963@qq.com \\ Haiyun $\mathrm{Wu}$ \\ College of Engineering and Technology \\ Tianjin Agricultural University \\ Tianjin, China \\ 283699240@qq.com
}

\author{
Hua Liu \\ College of Engineering and Technology \\ Tianjin Agricultural University \\ Tianjin, China \\ 41599386@qq.com \\ Ruokui Chang \\ College of Engineering and Technology \\ Tianjin Agricultural University \\ Tianjin, China \\ 529007475@qq.com
}

\begin{abstract}
Lesson planning is the basic and important step in the teaching process, which is a thinking skill that involves visualizing the lesson before it takes place and describing the detailed teaching process for an individual lesson. This paper firstly presents the OPME method and the OPME table for lesson planning based on the backward design method, the WIPPAE model and the ACRS model. OPME is an acronym which stands for objectives, process, method, and evaluation. And then, an example about how to use the OPME table to do the lesson planning is given, which shows that the OPME table is simple and practical.
\end{abstract}

Keywords-Lesson planning; OPME method; ACRS model

\section{LITERATURE REVIEW}

The process of previous preparation is the process of making a plan. In organization, planning is a management process of thinking about how to design and organize the activities to achieve the desired goals. Planning, which can increase the efficiency of an organization and reduce its risks, is the first step to do anything, including teaching process. Lesson planning is the basic and important unit in the teaching process, which is a thinking skill that involves visualizing the lesson before it takes place [1] and describing the detailed teaching process for an individual lesson. The process of lesson planning is determining the lesson topic, deriving the objectives or desired results, deciding the taught contents, and then designing the corresponding activities. Based on Jim Scrivener, lesson planning includes prediction, anticipation, and sequencing, organizing, and simplifying [2]. So, lesson planning can help teachers organize content, materials, time, instructional strategies, and assistance in classroom $[3,4]$.

Objectives are critical to an effective lesson. So, the objectives should be clear and can describe the intended learning outcomes [5]. According to the principles of backward design developed by Wiggins and McTighe, the lesson objectives can be divided from the whole objectives of the course, and then the instructors decide what they will accept as evidence of learner's knowledge and skills[6,7]. The main idea of the backward design is that the instructor must begin with the end in mind. That is, before beginning to do lesson planning, the instructor must firstly know what the students should know, understand, or do , and then determine the best way to reach the performance goal based on the students' current ability or skills[8] .

The design of the teaching process in the class is the key part in the lesson planning. In 1982, Madeline Hunter described her seven-step lesson plan, which is known as the "Madeline Hunter Method" or the "Madeline Hunter Direct Instruction Model", in her book---Mastery Teaching. The seven steps are anticipatory set, objectives/standards, teaching/modeling, guided practice, check for understanding, independent practice, and closure [9]. There are many variants of this model, and the WIPPEA model is one of these. The WIPPEA is an acronym that stands for Warm-up, Introduction, Presentation, Practice, Evaluation, and application. This is a lesson teaching model which represents a continuous teaching process [10].

The ARCS model of motivational design, which was created by John Keller, is one approach about how to find reliable and valid methods for motivating learners and how to stimulate and sustain learner motivation. The model is combined by four main areas: Attention, Relevance, Confidence, and Satisfaction. The name "ACRS" of the model is an acronym of the four main areas. Attention and relevance are essential to learning, and are considered the backbone of the ARCS theory. The attention in the theory refers to the learner's interest in what being taught. There are three different kinds of tactics to stimulate the learner's interest: perceptual arousal, inquiry arousal, and variability of teaching methods. The relevance is to build a relationship between the teaching contents and the learners. The three strategies Keller presents are goal orientation, motive matching, and familiarity. The key point about confidence aspect is to establish positive expectation for achieving success among the learners, and 
performance requirements, success opportunities, and personal control are three different kinds of confidence building strategies. Finally, the optimal effect of studying for learners is they can get a sense of satisfaction by the learning experience $[11,12]$. About motivation design, Keller provided a ten-step model. The ten steps include obtaining course information, obtaining audience information, analyzing audience, analyzing existing materials, listing objectives\& assessments, listing potential tactics, selecting \& designing tactics, integrating with instruction, selecting \& developing materials, and evaluation \& revise. With the English teaching, Keller designed a table about detailed lesson guide, where the ten-step model about the ACRS is used. [13]. Riyadh investigated the effect of projectbased learning and the ARCS motivational model on students' achievement and motivation to acquire database program skills. The results showed the students in the experimental group achieved higher post-curriculum test grades and obtained higher grades on the motivational scale [14].

\section{PROBLEM STATEMENT}

Most of the teachers in the university are recruited from the $\mathrm{PhD}$ graduates or post-doctors related to the relevant subjects. They have a deep professional knowledge and excellent scientific research ability. However, they are given little to no training during the course of our careers, especially for the day to day realities of lesson planning. So, some of them face with some of the most common challenges when lesson planning, such as a lack of preparation time and ideas, a tendency to over-plan and a failure to achieve the main objectives of the lesson . So, the aim of this paper is to answer how to make an effective and productive lesson planning, which is the OPME method.

\section{METHODOLOGY}

\section{A. OPME method}

Actually, the OPME method is the integration of the backward design method, the WIPPAE model and the ACRS model. The OPME is an acronym which stands for objectives, process, method, and evaluation. The method used in the lesson planning focus on addressing the following questions:

- What is expected for the learners?

- How is the lesson organized?

- How does the instructor effectively teach the required content?

- How does the instructor assess the learners' outcomes?

\section{B. Objectives}

Instructional objective is a description of a performance that instructor wants learners to be able to exhibit after they study the related course, which describes the intended result rather than the process of the instruction itself. An instructional objective should be specific, measurable, short-term, and observable to students' behaviors. Objectives are critical to effective instruction, because they can provide the direction to instruction and guidelines for assessment and help instructors to plan the instructional strategies and activities they will use. For a course, its instructional objectives are combined by course objectives, chapter objectives, and lesson objectives. It is a form of three levels. The objectives for a lesson are more specific and detailed than the other two. For a lesson planning, the objectives of the lesson are both its starting point and its end. Based on the characteristics of the instructional objectives, there are three types of objectives which are cognitive objective, psychomotor objective, and affective objective. The following are the three components of an instructional objective:

- Identifying the type of activity in which competence is required;

- Specifying the criteria or standards by which competence in the activity will be assessed;

- Listing any conditions or circumstances required for students to meet the objective.

\section{Process}

As mentioned above, the design of the teaching process in the class is the key part in the lesson planning. The teaching process is the process of conveying instructional contents to learners, which include the concepts and ideas that learners are expected to develop and specific knowledge and skills the learners are expected to acquire. According to the WIPPEA Model, the following teaching process is used in the paper, which includes the six steps----Warm-up, Introduction, Presentation, Practice, Application, and Summary. Because evaluation will happen in every step and will be done at the end of every step, it is taken to as one independent factor to explain later. The following gives the definitions of the six steps.

- Warm-up----Reviews previously learned content;

- Introduction----Introduces a broad overview of the content and concepts to be taught;

- Presentation----Teaches the lesson content and concepts;

- Practice----Models the skills and provides opportunities for guided practice.

- Application----Provides activities that help learners apply their learning to the new situations or contexts beyond the lesson and connect it to their own lives;

- Summary----Sum the important knowledges taught in the lesson.

\section{Methods}

According to the definition provided by Wikipedia, A teaching method comprises the principles and methods used for instruction to be implemented by teachers to achieve the desired learning in students. So, the teaching method is this kind of method about how to convey the teaching content to the learners and to achieve the intended outcomes in students. It is one necessary and critical part in the lesson planning. Generally, the teacher centered and student centered methods are two basic teaching approaches. In Teacher-Centered Approach to Learning, The primary role of teachers is to pass knowledge and information onto their students, and students' 
primary role is to passively receive information (via lectures and direct instruction) with an end goal of testing and assessment. Student learning is measured through objectively scored tests and assessments. In Student-Centered Approach to Learning, teachers and students play an equally active role in the learning process. The teacher's primary role is to coach and facilitate student learning and overall comprehension of material. Student learning is measured through both formal and informal forms of assessment, including group projects, student portfolios, and class participation. Teaching and assessments are connected; student learning is continuously measured during teacher instruction. The teaching methods are determined partly on subject matter to be taught and partly by the nature of the learner. For a particular teaching method to be appropriate and efficient it has to be in relation with the characteristic of the learner and the type of learning it is supposed to bring about and it can gain the learners' attention, build relevance between the teaching content and the students, establish positive confidence for success, lastly attain the intrinsic feelings of satisfaction. That is, the ACRS model is the standard to select and design a kind of teaching method. People always like a certain amount of variety and they will lose interest if the teaching methods, even the good ones, never change. So, the teaching methods used during the teaching should be of variation.

\section{E. Evaluation}

Learners' evaluation follows from the lesson objectives. According to the principles of backward design developed by Wiggins and McTighe, the lesson objectives can be derived from the whole objectives of the course, and then the instructors decide what they will accept as evidence of learner's knowledge and skills. Based on these, the learners' evaluation system for one course is built to assess tasks and attainment of learning outcomes, which includes oral, aural, written, or applied performance assessments.

\section{F. OPME table for lesson planning}

OPME table for lesson planning is a kind of lesson planning template designed based on the OPME method. This table focuses on the lesson objectives, teaching process, teaching strategies/methods, and the evaluation for students learning outcomes. It is simple and practical. In my opinion, the teaching design process of a course has three steps. The first step is to design the instructional objectives of the course, and the second step is to design the teaching design table about the course. Lesson planning is the third step. The first two steps are critical to the lesson planning because they provide the instructional direction of the course and the overall strategies to help the instructors to achieve the desired teaching objectives. The following is an example about how to use the OPME method to do the lesson planning in the course of Measurement \& Control Circuit.

\section{LESSON PLANNING ABOUT INTRODUCTION OF MEASUREMENT \& CONTROL CIRCUIT WITH OPME TABLE}

\section{A. Instructional objectives of Measurement \& Control Circuit}

Measurement and control circuit is a major course in the specialty of Measurement \& control technology and instrument, which is opened to the students in the senior year. The course mainly covers some circuit theories and application technologies related to the circuits used in the measurement and control system, which includes basic concepts related to the measuring and control circuit, device structure and modeling, circuit analysis, circuit design, circuit fault diagnosis and maintenance. After studying the course, students should possess the following abilities:

- Students will be able to describe and apply the analyzing methods to study the existing measuring and control circuit;

- Students will be able to diagnose the broken measuring circuit and repair it;

- Students will be able to design one measuring circuit according to the task requirement.

\section{B. Teaching design table}

As is known to all, teaching process is dynamic and complicated. In order to match this situation, teachers need to be flexible in their schedule and keep up with the changes of the teaching environment and technology. They must have all kinds of teaching strategies and skills to meet the teaching requirement. Students always like a certain amount of variety during listening to the class. Otherwise, they will lose interest. So, the main idea of teaching design about the course is integrated application of all kinds of teaching methods, which includes the traditional lecture-based teaching method, projectbased teaching method, the flipped classroom, question driven teaching method, and case study. The teaching design table is used to design the teaching process of the course. It includes the chapters to be taught in the course and main teaching strategies/methods used during the teaching process. The ARCS model of motivational design, which refers to attention, relevance, confidence, and satisfaction, will be used in the lesson planning to design the teaching process in every lesson. In the teaching design table, there are many small videos related to the contents of the corresponding chapters and that the students are familiar with. The average time of the videos is almost five minutes. By watching these videos before class, students can have the basic ideas related the contents that they will study. This kind of strategy is to grab the students' attention to the course.

\section{CONCLUSION}

The OPME method for lesson planning is presented in the paper. The tool used in the lesson planning is the OPME table. Actually, it is the integration of the backward design method, the WIPPAE model and the ACRS model. The OPME is an acronym which stands for objectives, process, method, and evaluation. The method used in the lesson planning focus on addressing the following questions: 
- What is expected for the learners?

- How is the lesson organized?

- How does the instructor effectively teach the required content?

- How does the instructor assess the learners' outcomes?

The example is about how to use the OPME table to do the lesson planning shows that the OPME table is simple and practical.

\section{ACKNOWLEDGMENT}

This work was financially supported by the Educational Reform project for the Experimental Teaching Center of Tianjin Agricultural University (2015SY016) and the Science Development Funds of Tianjin Agricultural University (2013S06).

\section{REFERENCES}

[1] Aura Poulsen, Khoa Lam, Sarah Cisneros, Torrey Trust.2008. ARCS Model of Motivational Design. Available at:

http://torreytrust.com/images/ITH_Trust.pdf. Accessed 5 October 2015.

[2] Aylett,Rose. 2015. Lessons in planning----a Process Approach to lesson planning. Professional Development. Available at: https://www.modernenglishteacher.com/uploadedFiles/Redbox/Pavilio n_Content/Our_Content/ELT/MET/MET2010s/MET2015/MET_243/Aylett.pdf. Accessed 8 October 2015

[3] Burns, Alvin C..2006. Teaching experientially with the Madeline Hunter Method: An application in a marketing research course. SIMULATION \& GAMING, Vol. 37 No. 2, pp. 284-294, June 2006

[4] Froelich, John.2009. Effective Lesson Design: A Basic Conceptual Outline. Available at: http://www.lookingatlearning. org/downloads/ Effective\% 20Lesson\%20Design.pdf. Accessed 8 October 2015.
[5] Graham,Sandra, and Bernard Weiner.Theories and Principles of Motivation. Available at:

http://www.unco.edu/cebs/psychology/kevinpugh/motivation_project/res ources/graham_weiner96.pdf. Accessed 8 October 2015.

[6] Heinich, R., Molenda, M., Russell, J., \& Smaldino, S. (2001). Instructional media and technologies for learning. Engle Cliffs (7th edition), NJ: Prentice Hall.

[7] Keller,John. 2000. How to integrate learner motivation planning into lesson planning: The ARCS model approach .Available at: https://pantherfile.uwm.edu/simonec/public/Motivation\%20retention\%2 Oarticles/Articles/Keller_IntegrateMotivationIntoLessonPlans.pdf. Accessed 10 October 2015.

[8] UL.2015. Tips for writing objectives. Available at: $\mathrm{http}: / / \mathrm{www} \cdot$ google.com/url?sa=t\&rct =j\&q=\&esrc= s\&f rm=1\&source= web\&cd=2\&ved=0ahUKEwigxNnUjtfJAhUK2WMKHTelC4gQFggiM AE\&url=http\%3A\%2F\%2Fwww.ulm.edu\%2F tallen\%2Fbin\%2FObject ive\%2520Tips.doc\&usg=AFQjCNHnm4NsKAXcunRPxCG0bEU7mN4 kow. Accessed at 10 October 2015.

[9] Riyadh Alhassan.2014. The effect of project-based learning and the ARCS motivational model on students' achievement and motivation to acquire database program skills. Journal of Education and Practice. Vol.5, No.21:158-164.

[10] Roulsen, Aura, Khoa Lam, Sarah Cisneros, and Torrey Trust.2008. ACRS Model of Motivation Design. Available at:

http://torreytrust.com/images/ITH_Trust.pdf. Accessed 10 October 2015.

[11] Sajjad, Shahida. Effective teaching methods at higher education level. Available at:

http://class.web.nthu.edu.tw/ezfiles/669/1669/img/1381/1.Effectiveteach ingmethodsathighereducationlevel.pdf. Accessed 12 October 2015.

[12] Tasmanian Department of Education (TDE).2004.Principle of Backward Design. Available at:

https://www.wku.edu/library/dlps/infolit/documents/designing_lesson_p lans_using_backward_design.pdf. Accessed 10 October 2015.

[13] TEAL Center Staff.2010. Effective Lesson Planning. Available at: https://teal.ed.gov/sites/default/files/FactSheets/8_TEAL_Lesson_Planning.pdf. Accessed 1 October 2015.

[14] TEACH.2015.Teaching Method. Available at: http://teach.com/what/teachers-teach/teaching-methods. Accessed 13 October 2015. 